FNG \& Bilim Tıp Dergisi 2015;1(1):1-6 doi: 10.5606/fng.btd.2015.001

\title{
A randomized, crossover model-based study of five different laryngoscopes in normal airway scenario
}

\author{
Normal havayolu senaryosunda beş farklı laringoskopa ait randomize, \\ crossover, manken bazlı bir çalışma
}

\author{
Ayten Saraçoğlu, ${ }^{1}$ Engin Hüsnü Uğur, ${ }^{1}$ Olgaç Bezen, ${ }^{2}$ Sibel Şener, ${ }^{2}$ Fisun Yüzer, ${ }^{1}$ Nüzhet Mert Şentürk ${ }^{3}$ \\ ${ }^{1}$ Department of Anaesthesiology and Reanimation, Medical Faculty of İstanbul Bilim University, İstanbul, Turkey \\ ${ }^{2}$ Department of Anaesthesiology and Reanimation, İstanbul Bilim University Health Services Vocational High School, İstanbul, Turkey \\ ${ }^{3}$ Department of Anaesthesiology and Reanimation, İstanbul University İstanbul Medical School, İstanbul, Turkey
}

\begin{abstract}
Objectives: Direct laryngoscopy is a conventional method that has been taught in endotracheal intubation training. However, it is difficult to become skilled. Videolaryngoscopy has become a widely accepted technique for training both novice and inexperienced medical staff on airway management. We aimed to compare the performances of novices using direct and indirect laryngoscopes.

Materials and methods: Fifty eight first-year anesthesia nurse students without previous tracheal intubation experience were included in the study. Standard size 3 Macintosh, Miller, McCoy, McGrath, Storz C-Mac laryngoscopes were used. The participants were asked to intubate the AirMan manikin five times with each device. The participants were also asked for their familiarity with computer games. After all the students completed their fifth intubations; the duration of successful tracheal intubation, number of attempts, success rate, severity of the dental trauma, and the used optimization maneuvers were recorded in the course of students' sixth intubations.

Results: Time to successful intubation was the shortest for C-Mac laryngoscope with $5.34 \pm 2.19 \mathrm{sec}$. The requirement of optimization maneuvers (12.1\%) and additional intubation attempts (1.7\%) were significantly lower with C-Mac and McGrath laryngoscopes compared to Macintosh, Miller and McCoy laryngoscopes $(p<0.001)$. Dental trauma incidence was significantly lower during the use of C-Mac laryngoscope $(p<0.001)$. The VAS score on the ease of intubation were significantly lower with C-Mac laryngoscope. No advantages related to the familiarity with computer games were documented.

Conclusion: In conclusion, C-Mac was observed to provide a higher overall success rate for tracheal intubation and less dental trauma incidence when it was used in a normal airway scenario.
\end{abstract}

Keywords: Airway; intubation; laryngoscope.

\section{$\ddot{o z z}$}

Amaç: Direkt laringoskopi trakeal entübasyon eğitiminde kullanılan geleneksel bir metoddur. Ancak bu alanda ustalaşmak zordur. Videolaringoskopi havayolu yönetiminde deneyimsiz medikal personel eğitimi için yaygın olarak kabul görmüş bir tekniktir. Bu çalışmada deneyimsiz kullanıııların direkt ve indirekt laringoskoplardaki performanslarını karşılaştırmayı amaçladık.

Gereç ve yöntemler: Daha önce trakeal entübasyon deneyimi bulunmayan 58 birinci sınıf anestezi teknikerliği öğrencisi çalışmaya dahil edildi. Standart 3 no'lu Macintosh, Miller, McCoy, McGrath, Storz C-Mac laringoskopları kullanıldı. Katılımcılardan AirMan mankeni her aygıtla beşer kez entübe etmeleri istendi. Katılımcıların bilgisayar oyunlarına karşı yatkınlıkları da sorgulandı. Tüm öğrenciler beşinci entübasyonlarını tamamladığında altıncı entübasyonları için başarılı trakeal entübasyon süresi, girişim sayısı, başarı oranı, dental travma şiddeti ve kullanılan optimizasyon manevraları kaydedildi.

Bulgular: Başarılı entübasyon süresi 5.34 \pm 2.19 sn ile C-Mac laringoskop için en düşüktü. Optimizasyon manevra gereksinimi ve ek entübasyon girişimleri C-Mac ve McGrath laringoskoplar için Macintosh, Miller and McCoy laringoskoplarla karşılaştırıldığında anlamlı olarak daha düşüktü ( $p<0.001)$. Dental travma insidansı C-Mac laringoskop kullanımında anlamlı olarak daha düşüktü $(p<0.001)$. Entübasyon kolaylığı üzerine Görsel analog skala skorları C-Mac laringoskopla anlamlı olarak daha düşüktü. Bilgisayar oyunlarına yatkınlıkla ilişkili bir avantaj dökümente edilemedi.

Sonuç: Sonuç olarak normal havayolu senaryosunda C-Mac'ın trakeal entübasyon için daha yüksek genel başarı oranı ve daha düşük dental travma insidansı sağladığı ortaya konuldu.

Anahtar sözcükler: Havayolu; entübasyon; laringoskop.

Received: April 17, 2015 Accepted: May 02, 2015

Correspondence: Olgaç Bezen, MD. Şişli Florence Nightingale Hastanesi Anesteziyoloji ve Reanimasyon Kliniği, 34349 Çağlayan, Istanbul, Turkey.

Tel: +90 533-6035985 e-mail: drbezen@yahoo.com

Presented at the $47^{\text {th }}$ Turkish Society of Anesthesiology and Reanimation Congress November 20-24, Antalya, Turkey (Reinhard Purschke Prize). 
Direct laryngoscopy is a conventional method that has been taught in endotracheal intubation training. ${ }^{[1]}$ However, as it requires alignment of pharyngeal, laryngeal and tracheal axes, it may be difficult or impossible in selected patients. Additionally, it is difficult to become skilled at this method. ${ }^{[2,3]}$ There are several options of laryngoscope blades available for anesthetists' use in routine practice. ${ }^{[4]}$ Videolaryngoscopy has become a widely accepted technique for training both novice and inexperienced medical staff on airway management. ${ }^{[5-7]}$ In cases where neither direct laryngoscopy nor tracheal intubation is achieved, videolaryngoscopes generally secure the glottic view with less manipulation as compared to direct laryngoscopes. Besides, because learning the technique is relatively easy, videolaryngoscopy brings high success rates even for beginners. ${ }^{[8]}$

The McCoy laryngoscope (InterMed Penlon Ltd., Abingdon, UK) has been designed to elevate the epiglottis with its hinged tip. That design has two advantages over Macintosh laryngoscope (Welch Allyn, Skaneateles Falls, New York, USA): First, as less force is required during laryngoscopy, the stress level decreases, accordingly. Second, elevation of epiglottis allows improved laryngeal visualization. ${ }^{[9]}$ The Storz C-Mac laryngoscope is a modification of the Karl Storz Berci DCI laryngoscope (Karl Storz, Tuttlingen, Germany) with an improved optical system, improved field of view, higher video quality and easy recording of still pictures and motion video. ${ }^{[10]}$ The McGrath videolaryngoscope (Aircraft Medical, Ltd, Edinburgh, UK) has a liquid-crystal display (LCD) screen on the top of its handle and a slim acrylic cover with a $60^{\circ}$ angulation which provides an indirect view of the glottis. ${ }^{[11]}$

In this study, we aimed to compare the performances of novices using direct and indirect laryngoscopes.

\section{MATERIALS AND METHODS}

After the Institutional Ethics Committee approval and written informed consents, 58 first-year anesthesia nurse students without previous tracheal intubation experience were included in the study. Following the oral instructions regarding the correct use of standard size 3 Macintosh, Miller, McCoy, McGrath, Storz C-Mac laryngoscope and the use of a stylet, the students watched video presentations on the use of each device. After the presentations, the participants were allowed $10 \mathrm{~min}$ to familiarize themselves with the laryngoscopes and the manikin. Then the participants were asked to intubate the AirMan manikin five times with each device.

In a randomized crossover design, each participants performed tracheal intubations with one laryngoscope and then the other ones. The order of the devices was randomized using computer generated random numbers table. The manikin was set to normal airway setting in supine position. The primary endpoint was the duration of intubation attempt. After all the students completed their fifth intubations; the duration of successful tracheal intubation, number of attempts, success rate, severity of the dental trauma, and the used optimization maneuvers (head extension, vertical lifting, assistance and device rotation) were recorded in the course of students' sixth intubations. All laryngoscopes were used according to manufacturers' instructions. The students were also asked to assess the ease of use and maneuverability of each of the five devices on a $100 \mathrm{~mm}$ visual analog scale (VAS). At the end, all participants filled in a short questionnaire of five questions. All of the intubations were performed with cuffed lubricated endotracheal tube with inner diameter of $7.5 \mathrm{~mm}$, and a rigid stylet. The stop-watch was started as soon as the participants took airway instruments in hand, and it was stopped when the endotracheal tubes passed through the vocal cords. A different researcher other than the trainer kept the records and verified intubations with the inflation of manikin's lungs. In case of failure in providing airway within two minutes or in completing the procedure, the esophageal intubation considered unsuccessful. Occurrence of dental trauma was assessed according to the applied pressure on teeth during tracheal intubation.

The participants were asked to reply to the question: "If you consider the ease of use and learnability, which instrument would you prefer to use for intubation?" by using a $100 \mathrm{~mm}$ VAS; 0: extremely difficult to learn and use, 100: extremely easy to learn and use. The hand dominance and experience with computer games more than one hour per week during last 10 years were asked and recorded. 
Table 1. Time to successful intubation

\begin{tabular}{|c|c|c|c|c|c|}
\hline & Macintosh & Miller & McCoy & McGrath & C-Mac \\
\hline & Mean \pm SD & Mean \pm SD & Mean \pm SD & $\overline{M e a n} \pm S D$ & Mean \pm SD \\
\hline Time (sec) & $10.62 \pm 7.95^{*} \neq$ & $8.68 \pm 3.60^{*} \neq$ & $10.07 \pm 5.53^{*} \neq$ & $7.59 \pm 5.32^{*}$ & $5.34 \pm 2.19$ \\
\hline
\end{tabular}

Students who did not provide written consent and had previous intubation experience with one of the five laryngoscopes were excluded from the study. Both the researcher explaining the procedure and informing students and the other researcher keeping records were professional anesthetists with at least five-year experience.

\section{Statistical analysis}

We calculated sample size from a preliminary study including 10 students. The mean \pm standard deviation time required to ventilate the lungs after tracheal intubation in manikin was $10.8 \pm 4.6 \mathrm{~s}$. We considered that a difference of $2.5 \mathrm{~s}$ (roughly one quarter of $10.8 \mathrm{~s}$ ) between the groups would be clinically important. To detect this difference with a power of $80 \%(\alpha=0.05$, $\beta=0.2$ and effect size $=0.56$ ) approximately 51 participants would be needed. IBM SPSS software version 21.0 (IBM Corp. Armonk, NY USA) was used for statistical analyses. The frequency, rate, average and standard deviation values were used for the descriptive statistics of the data. Distribution of the variances was controlled by using the Kolmogorov-simirnov test. Chi-square test was used for analyzing qualitative data and Mann-Whitney $U$ test in quantitative data analysis. While the Friedman test was used for the analysis of repeated measurements, the Wilcoxon test, the Cochran's $\mathrm{Q}$ test and the Mc Nemar's test were used for sub-analyses.

\section{RESULTS}

Fifty-eight students studying anesthesiology for a career as a nurse were informed about the research and invited to take part in the study. All students were recruited to the study without exclusion. Time to successful intubation was the shortest for C-Mac laryngoscope with $5.34 \pm 2.19 \mathrm{sec}$ (Table 1). Time to successful intubation was significantly shorter with McGrath laryngoscope when compared to Macintosh, Miller and McCoy laryngoscopes $(\mathrm{p}<0.05)$. The requirement of optimization maneuvers (12.1\%) and additional intubation attempts (1.7\%) were significantly lower with C-Mac and McGrath laryngoscopes compared to Macintosh, Miller and McCoy laryngoscopes $(\mathrm{p}<0.001)$ (Table 2). Dental trauma incidence was significantly lower during the use of C-Mac laryngoscope $(p<0.001)$ (Table 2). The VAS score on the ease of intubation was found to be significantly lower for the C-Mac laryngoscope when compared to Macintosh, Miller, McCoy and McGrath laryngoscopes $(p<0.001)$ (Table 3). The VAS score on the ease of intubation was significantly lower for McGrath

Table 2. Optimization maneuver rates, dental trauma incidence and the incidence of additional intubation attempts (\%)

\begin{tabular}{|c|c|c|c|c|c|c|c|c|c|c|}
\hline & \multicolumn{2}{|c|}{ Macintosh } & \multicolumn{2}{|c|}{ Miller } & \multicolumn{2}{|c|}{ McCoy } & \multicolumn{2}{|c|}{ McGrath } & \multicolumn{2}{|c|}{ C-Mac } \\
\hline & $\mathrm{n}$ & $\%$ & $\mathrm{n}$ & $\%$ & $\mathrm{n}$ & $\%$ & $\mathrm{n}$ & $\%$ & $\mathrm{n}$ & $\%$ \\
\hline Optimization maneuvers & 55 & $94.8^{*} \neq$ & 55 & $94.8^{*} \neq$ & 50 & $86.2^{*} \neq$ & 7 & 12.1 & 7 & 12.1 \\
\hline Dental trauma incidence & 57 & $98.3^{*} \neq$ & 54 & $93.1^{*} \neq$ & 54 & $93.1^{*} \neq$ & 30 & $51.7^{*}$ & 21 & 36.2 \\
\hline Additional intubation attempts & 10 & $17.2^{*} \neq$ & 8 & $13.8^{*} \neq$ & 3 & 5.2 & 1 & 1.7 & 1 & 1.7 \\
\hline
\end{tabular}

* Comparison with C-Mac laryngoscope, $p<0.001 ;$ ₹ Comparison with McGrath laryngoscope, $p<0.001$.

Table 3. The visual analog scale scores on the ease of tracheal intubation $(\mathrm{mm})$

\begin{tabular}{|c|c|c|c|c|c|}
\hline & Macintosh & Miller & McCoy & McGrath & C-Mac \\
\hline & Mean \pm SD & Mean \pm SD & Mean \pm SD & Mean \pm SD & Mean \pm SD \\
\hline Time (sec) & $29.83 \pm 21.76 * \neq$ & $43.53 \pm 30.25^{*} \neq \dagger$ & $40.69 \pm 22.84^{*} \neq \dagger$ & $12.24 \pm 11.86^{*}$ & $7.59 \pm 7.45$ \\
\hline
\end{tabular}

SD: Standard deviation; * Comparison with C-Mac, $p<0.001$; $\neq$ Comparison with McGrath, $p<0.001$; $\dagger$ Comparison with Macintosh, $p<0.001$. 
Table 4. The comparison of participants familiar and unfamiliar with computer games with regard to time to successful intubation and difficulty visual analog scale scores

\begin{tabular}{lcccc}
\hline & Playing computer games $(+)$ & & Playing computer games $(-)$ \\
& Mean \pm SD & & Mean \pm SD & \\
\hline Time to successful tracheal intubation (sec) & $8.21 \pm 4.18$ & $12.87 \pm 9.85$ & 0.039 \\
Macintosh & $8.36 \pm 3.72$ & $9.00 \pm 3.51$ & 0.468 \\
Miller & $8.89 \pm 4.13$ & $11.17 \pm 6.45$ & 0.071 \\
McCoy & $6.18 \pm 2.94$ & $8.90 \pm 6.62$ & 0.121 \\
McGrath & $4.96 \pm 1.97$ & $5.70 \pm 2.35$ & 0.259 \\
C-Mac & & & \\
Visual analog scale (mm) & $27.75 \pm 22.60$ & $31.77 \pm 21.14$ & 0.487 \\
Macintosh & $42.07 \pm 32.86$ & $44.90 \pm 28.09$ & 0.725 \\
Miller & $40.18 \pm 22.50$ & $41.17 \pm 23.51$ & 0.871 \\
McCoy & $11.79 \pm 13.00$ & $12.67 \pm 10.89$ & 0.780 \\
McGrath & $9.04 \pm 8.84$ & $6.23 \pm 5.70$ & 0.154 \\
C-Mac & & & \\
\hline
\end{tabular}

SD: Standard deviation.

than Macintosh, Miller and McCoy laryngoscopes $(p<0.001)$. The VAS score was significantly lower for Macintosh laryngoscope than Miller and McCoy laryngoscopes $(p<0.001)$ (Table 3).

Novice users who were familiar with computer games successfully intubated the manikin with Macintosh laryngoscope in a significantly shorter time as compared to the ones who were not familiar with computer games $(p=0.039)$. However, the time required for successful intubation of the manikin did not show any significant difference between Miller, McCoy, McGrath and C-Mac laryngoscopes (Table 4). The VAS scores on the ease of tracheal intubation did not differ between participants who were familiar or unfamiliar to computer games (Table 4). The analyzed data from the questionnaire results are shown in Table 5.

\section{DISCUSSION}

This study compared videolaryngoscopes with direct laryngoscopes in tracheal intubation training for novices, and found that Storz C-Mac laryngoscopes were advantageous regarding the shortest time to successful intubation. They also yielded the lowest dental trauma score, the least optimization maneuver requirement and ease of use. The participants who regularly play computer games intubated the manikin quicker using the Macintosh laryngoscope. The Storz C-Mac videolaryngoscope was found to be superior to the McGrath laryngoscope in all measurements performed within the scope of this study. We recorded a difference of 2.25 seconds between successful intubation times of these two videolaryngoscopes. Much longer difference (17 seconds) was observed in a study contrasting McGrath and C-Mac laryngoscopes on 130 patients with the Mallampati grade of $\geq 3$ who poses the potential for difficult intubation. ${ }^{[12]}$ In our study, participants stated that $\mathrm{C}-\mathrm{Mac}$ may provide a much easier intubation as compared to the other laryngoscopes. This may be attributed to C-Mac having a Macintosh-like blade and that intubation was performed with a camera. As McGrath has a

Table 5. Analyzed data from the questionnaire results

\begin{tabular}{|c|c|c|c|c|c|c|c|c|c|c|}
\hline & \multicolumn{2}{|c|}{ Macintosh } & \multicolumn{2}{|c|}{ Miller } & \multicolumn{2}{|c|}{ McCoy } & \multicolumn{2}{|c|}{ McGrath } & \multicolumn{2}{|c|}{ C-Mac } \\
\hline & $\mathrm{n}$ & $\%$ & $\mathrm{n}$ & $\%$ & $\mathrm{n}$ & $\%$ & $\mathrm{n}$ & $\%$ & n & $\%$ \\
\hline $\begin{array}{l}\text { Which was the easiest device for } \\
\text { endotracheal entubation? }\end{array}$ & 1 & 1.7 & 9 & 15.5 & 0 & 0 & 23 & 39.7 & 19 & 32.8 \\
\hline $\begin{array}{l}\text { Which device was easier to } \\
\text { make maneuver? }\end{array}$ & 0 & 0 & 1 & 1.7 & 1 & 1.7 & 19 & 32.8 & 27 & 46.6 \\
\hline $\begin{array}{l}\text { Which device did you feel more } \\
\text { confident? }\end{array}$ & 1 & 1.7 & 2 & 3.4 & 0 & 0 & 12 & 20.7 & 1 & 1.7 \\
\hline $\begin{array}{l}\text { Which device did you expect the } \\
\text { most complications? }\end{array}$ & 11 & 19.0 & 7 & 12.1 & 9 & 15.5 & 1 & 1.7 & 11 & 19.0 \\
\hline $\begin{array}{l}\text { Which device did you get } \\
\text { accustomed to use? }\end{array}$ & 45 & 77.6 & 39 & 67.2 & 48 & 82.8 & 3 & 5.2 & 0 & 0 \\
\hline
\end{tabular}


steep curve, the tube cannot be directed without a stylet. This feature may have created difficulty for users while performing intubation with the McGrath laryngoscope. As C-Mac with the easiest use required fewer optimization maneuvers, it led to lower dental trauma score. In our study, the McGrath laryngoscope was documented to have advantages over both curved-blade and straight-blade laryngoscopes with consideration to tracheal intubation time, number of attempts, dental trauma severity, and ease of use. The disposable, slim, acrylic cover fixed on the blade of McGrath provides an indirect glottic view with a $60^{\circ}$ angulation. We believe that, thanks to that characteristic, the time to intubation may be shorter with McGrath in comparison with the other direct laryngoscopes. Similar to our study, in Ray et al. ${ }^{[13]}$ novices reported that McGrath provided a higher overall success rate for tracheal intubation and less dental trauma incidence than Macintosh laryngoscope. On the other hand, another study compared McGrath with straight blades but could not display any superiority in terms of clinical results. ${ }^{[14]}$ However, differently from our study, Mallampati grade of $\geq 3$ patients having potential for difficult intubation were included in the study mentioned above. Although experience with video game play have been reported to have some negative effects, ${ }^{[15]}$ we discovered a positive correlation in psychomotor skills of those participants who played video games on a regular basis. Previous studies have shown that residents who are interested in video games have better visual, spatial, and motor coordination. ${ }^{[16-19]}$ It was also indicated that such residents can quickly learn endoscopical techniques and perform better. ${ }^{[20]}$ Nonetheless, studies have also compared computer game players with non-players and lefthand dominance with right-hand dominance in the context of laparoscopic surgery training and determined that right-hand dominance provided fewer unnecessary movements, faster learning, and fewer errors. ${ }^{[21]}$ In the same study, residents having experience with computer games made fewer mistakes than non-players.

Liquid-crystal display displays of videolaryngoscopes are used for guiding and verifying the direction of ETT. Losing the 3D visual depth on the screen may affect the time and success while inserting the tube. This study compared participants regarding their familiarity with computer games. While familiarity with computer games did not create any significant difference in the use of videolaryngoscopes, it did shorten the average time to tracheal intubation when the Macintosh blade was used. In that regard, we believe that further studies can be planned on the learning curves of fiberoptic bronchoscopy and/or videolaryngoscopy use.

Although C-Mac and McGrath had been clinically compared before, to the best of our knowledge, this is the first randomized crossover study that has been conducted with novices using normal airway simulation and that has contrasted these two laryngoscopes with conventional methods. Previous studies have indicated that trials performed using 'ideal' mannequins yield similar results when compared with patients in a clinic. ${ }^{[22]}$ However, data obtained from mannequin studies cannot be directly transferred to the clinical practice because some factors which may develop during laryngoscopy - such as bleeding, secretions and fogging - cannot be simulated in mannequin studies. This constitutes one of the limitations of this study.

In conclusion, C-Mac was observed to provide a higher overall success rate for tracheal intubation and less dental trauma incidence when it was used in a mannequin scenario. We could not document any advantages related to the familiarity with computer games.

\section{Declaration of conflicting interests}

The authors declared no conflicts of interest with respect to the authorship and/or publication of this article.

\section{Funding}

The authors received no financial support for the research and/or authorship of this article.

\section{REFERENCES}

1. Mosier J, Chiu S, Patanwala AE, Sakles JC. A comparison of the GlideScope video laryngoscope to the C-MAC video laryngoscope for intubation in the emergency department. Ann Emerg Med 2013;61:414-420.

2. Wang HE, Seitz SR, Hostler D, Yealy DM. Defining the learning curve for paramedic student endotracheal intubation. Prehosp Emerg Care 2005;9:156-62.

3. Mulcaster JT, Mills J, Hung OR, MacQuarrie K, Law JA, Pytka S, et al. Laryngoscopic intubation: learning and performance. Anesthesiology 2003;98:23-7. 
4. Sethuraman D, Darshane S, Guha A, Charters $P$. A randomised, crossover study of the Dorges, McCoy and Macintosh laryngoscope blades in a simulated difficult intubation scenario. Anaesthesia 2006;61:482-7.

5. Nouruzi-Sedeh P, Schumann M, Groeben $\mathrm{H}$. Laryngoscopy via Macintosh blade versus GlideScope: success rate and time for endotracheal intubation in untrained medical personnel. Anesthesiology 2009;110:32-7.

6. Miki $\mathrm{T}$, Inagawa $\mathrm{G}$, Kikuchi $\mathrm{T}$, Koyama $\mathrm{Y}$, Goto T. Evaluation of the Airway Scope, a new video laryngoscope, in tracheal intubation by naive operators: a manikin study. Acta Anaesthesiol Scand 2007;51:1378-81.

7. Woollard M, Mannion W, Lighton D, Johns I, O'meara $\mathrm{P}$, Cotton $\mathrm{C}$, et al. Use of the Airtraq laryngoscope in a model of difficult intubation by prehospital providers not previously trained in laryngoscopy. Anaesthesia 2007;62:1061-5.

8. Wetsch WA, Hellmich M, Spelten O, Schier R, Böttiger BW, Hinkelbein J. Tracheal intubation in the ice-pick position with video laryngoscopes: a randomised controlled trial in a manikin. Eur $\mathrm{J}$ Anaesthesiol 2013;30:537-43.

9. Bilgin $\mathrm{H}$, Bozkurt $\mathrm{M}$. Tracheal intubation using the ILMA, C-Trach or McCoy laryngoscope in patients with simulated cervical spine injury. Anaesthesia 2006;61:685-91.

10. Aziz M, Brambrink A. The Storz C-MAC video laryngoscope: description of a new device, case report, and brief case series. J Clin Anesth 2011;23:149-52.

11. Burdett E, Ross-Anderson DJ, Makepeace J, Bassett PA, Clarke SG, Mitchell V. Randomized controlled trial of the A.P. Advance, McGrath, and Macintosh laryngoscopes in normal and difficult intubation scenarios: a manikin study. $\mathrm{Br} \mathrm{J}$ Anaesth 2011;107:983-8.

12. Ng I, Hill AL, Williams DL, Lee K, Segal R. Randomized controlled trial comparing the McGrath videolaryngoscope with the $\mathrm{C}-\mathrm{MAC}$ videolaryngoscope in intubating adult patients with potential difficult airways. Br J Anaesth 2012;109:439-43.

13. Ray DC, Billington C, Kearns PK, Kirkbride R, Mackintosh K, Reeve CS, et al. A comparison of McGrath and Macintosh laryngoscopes in novice users: a manikin study. Anaesthesia 2009;64:1207-10.

14. Ng I, Sim XL, Williams D, Segal R. A randomised controlled trial comparing the McGrath( $\left({ }^{\circledR}\right)$ videolaryngoscope with the straight blade laryngoscope when used in adult patients with potential difficult airways. Anaesthesia 2011;66:709-14.

15. Kennedy AM, Boyle EM, Traynor O, Walsh T, Hill AD. Video gaming enhances psychomotor skills but not visuospatial and perceptual abilities in surgical trainees. J Surg Educ 2011;68:414-20.

16. Adams BJ, Margaron F, Kaplan BJ. Comparing video games and laparoscopic simulators in the development of laparoscopic skills in surgical residents. J Surg Educ 2012;69:714-7.

17. Giannotti D, Patrizi G, Di Rocco G, Vestri AR, Semproni CP, Fiengo L, et al. Play to become a surgeon: impact of Nintendo Wii training on laparoscopic skills. PLoS One 2013;8:57372.

18. Green CS, Bavelier D. Action video game modifies visual selective attention. Nature 2003;423:534-7.

19. Rosser JC Jr, Lynch PJ, Cuddihy L, Gentile DA, Klonsky J, Merrell R. The impact of video games on training surgeons in the 21st century. Arch Surg 2007;142:181-6.

20. Lynch J, Aughwane P, Hammond TM. Video games and surgical ability: a literature review. J Surg Educ 2010;67:184-9.

21. Grantcharov TP, Bardram L, Funch-Jensen P, Rosenberg J. Impact of hand dominance, gender, and experience with computer games on performance in virtual reality laparoscopy. Surg Endosc 2003;17:1082-5.

22. Malik MA, O’Donoghue C, Carney J, Maharaj CH, Harte BH, Laffey JG. Comparison of the Glidescope, the Pentax AWS, and the Truview EVO2 with the Macintosh laryngoscope in experienced anaesthetists: a manikin study. Br J Anaesth 2009;102:128-34. 